\title{
PENGGUNAAN BAHASA YAFILA DI DESA YAFILA, KECAMATAN AMAHAI, KABUPATEN MALUKU TENGAH
}

\author{
Erlinda Polsiary \\ Romilda Arivina da Costa \\ Universitas Pattimura \\ e-mail: ronaromilda70@gmail.com
}

\begin{abstract}
Abstrak
Kondisi bahasa-bahasa daerah di Maluku semakin terdesak. Oleh sebab itu, perlu ditelisik satu per satu. Penelitian ini mengangkat bahasa Teon yang digunakan di Desa Yafila, Kabupaten Maluku Tengah, yang dinamakan bahasa Yafila (BYF). Pentingnya penelitian ini didasarkan pada kondisi penutur BYF sebagai para migran yang sebagian besar bukan lagi monolingual bahasa Teon, lingkungan sekitar yang multietnis, pendidikan, serta jarak yang relatif dekat dengan pusat kota kabupaten sehingga mereka juga kerap menggunakan bahasa Melayu Ambon (BMA). Data penggunaan BYF dijaring dengan teknik observasi, kuesioner, dan wawancara, kemudian disajikan dalam tabel frekuensi dan dideskripsikan secara kualitatif. Hasil penelitian menunjukkan bahwa kekerapan penggunaan BYF hanya berkisar antara $50 \%-58 \%$.
\end{abstract}

Kata Kunci: bahasa Yafila, penutur, penggunaan, kekerapan 


\title{
THE USE OF YAFILA LANGUAGE IN THE YAFILA VILLAGE, DISTRICT OF AMAHAI, DISTRICT OF CENTRAL MALUKU
}

\author{
Erlinda Polsiary \\ Romilda Arivina da Costa \\ Universitas Pattimura \\ e-mail: ronaromilda70@gmail.com
}

\begin{abstract}
The existence of local languages in Maluku Province is on the verge of extinction. Thus, a comprehensive evaluation towards the issue is necessary. The present study analyses the use of Teon language in Yafila Village (Bahasa Yafila hereof BYF), Central Maluku. This study is based on the actual condition of the inhabitants who predominantly are the migrants from various multiethnic origins, different education level along with relatively close distance to the district center which cause them use Ambon Malay or Bahasa Melayu Ambon (BMA) instead of local Teon language. Data about BYF was collected through observation technique, questionnaire, and interview. The process was then followed by presenting the table of frequency and finally the data was qualitatively described. The result shows that the frequency of BYF language use is range from $50 \%$ to $58 \%$.
\end{abstract}

Keywords: Bahasa Yafila, speaker, language use, frequency 


\section{A. PENDAHULUAN}

Salah satu kecenderungan yang tampak jelas dalam dinamika kehidupan manusia dewasa ini adalah perubahan-perubahan yang kian cepat sebagai dampak dari upaya-upaya manusia mengembangkan ilmu pengetahuan dan teknologi. Perubahanperubahan itu tentu saja sangat berpengaruh terhadap berbagai aspek kehidupan masyarakat. Demikian pula halnya dengan perubahan sosial yang dapat disebabkan oleh lingkungan fisik, populasi, penemuan baru, difusi kultural, gagasan baru, krisis atau konflik, ataupun lahirnya kebijakan baru. Perubahan sosial ini biasanya terkait dengan perubahan budaya, seperti perubahan dalam norma-norma, kepercayaan, dan materi budaya yang pada gilirannya tercermin pada penggunaan bahasa. Dikatakan demikian karena bahasa pada hakikatnya merupakan cerminan pola pikir penuturnya, yaitu pelaku sosial sekaligus insan budaya. Sementara fenomena budaya, apa pun bentuknya termasuk bahasa mempunyai posisi yang tidaklah stabil.

Kondisi bahasa-bahasa daerah di Maluku sebagai bagian dari budaya Nusantara saat ini sangat terdesak oleh perkembangan zaman dan teknologi informasi. Padahal, bahasa-bahasa daerah sesungguhnya adalah tiang-tiang penopang kebudayaan Indonesia yang peran dan fungsinya amat mendasar. Jika tiang itu keropos, akan runtuh pula bangunan kebudayaan yang ditopangnya. Oleh karena itu, tidaklah salah bila banyak orang mulai berpikir untuk mempertahankannya, atau melestarikannya jika sudah terlanjur mati. Sebelum kekayaan budaya ini hanya tinggal dalam keindahan statistik, perlu kesadaran penuh untuk mulai menelisik kondisi bahasa-bahasa tersebut satu per satu sebab daya hidup bukan hanya berbicara mengenai kekuatan dan ketahanan, melainkan juga kegerakan atau tindakan untuk memulai.

Salah satu bahasa di Maluku yang perlu mendapat perhatian adalah bahasa Teon. Penutur bahasa ini semula berdiam di Pulau Teon yang merupakan salah satu pulau dari gugusan Kepulauan Teon Nila Serua (TNS) yang terletak paling selatan dalam wilayah Kabupaten Maluku Tengah, serta berdekatan dengan Pulau Damar dan Kepulauan Tanimbar. Penutur bahasa Teon mendiami 5 desa di pulau tersebut, yaitu Desa Watludan, Layeni, Isu, Mesa, dan Yafila.

Pada tahun 1978 masyarakat Kepulauan TNS dipindahkan ke Pulau Seram, akibat ancaman tiga gunung berapi aktif, yaitu G. Fausulu di Pulau Teon, G. Laworkarwa di Pulau Nila, dan G. Hutuloura di Pulau Serua Pada saat itu seluruh desa di Kepulauan TNS dipindahkan ke Pulau Seram, termasuk Desa Yafila (http://almascetie.wordpress.com). Di Seram masyarakat TNS daerah Waipia di Seram tengah bagian selatan oleh pemerintah, yang kemudian dikenal sebagai Kecamatan TNS, dengan ibukotanya di Desa Layeni (Ayawaila, 2005: 18). Dalam proses penempatan itu, masyarakat Desa Yafila satu-satunya yang tidak ikut karena masih berharap dapat kembali ke Pulau Teon. Jadilah masyarakat ini menempati bagian dari wilayah Kecamatan Amahai sekalipun mengalami beberapa kali perpindahan karena berbagai faktor (lih. bagian Pembahasan).

Bahasa Teon yang menjadi objek penelitian ini adalah bahasa Teon yang digunakan di Desa Yafila, Pulau Seram yang oleh masyarakatnya sendiri dinamakan 
bahasa Yafila (selanjutnya disebut BYF) karena aspek perbedaan fonologis dan beberapa kosakata sehingga secara awam dianggap sebagai perbedaan dengan bahasa Teon yang dituturkan di keempat desa yang lain oleh sebagian penuturnya (SIL, 2006: 97). Penggunaan BYF dianggap penting untuk diteliti sehubungan dengan kondisi penuturnya sebagai para migran, lingkungan sekitar yang multietnis, serta jarak yang relatif dekat dengan Kota Masohi, Ibukota Kabupaten Maluku Tengah yang membuat mereka sering menggunakan bahasa Melayu Ambon (selanjutnya disebut BMA) sebagai bahasa penghubung (lingua franca).

Kondisi di atas membuat bahasa Yafila semakin bergeser karena sewaktu masih di Pulau Teon sendiri, para penuturnya bukan lagi penutur yang monolingual Teon. Collins (2018: 133) mencatat bahwa sejak tahun 1890-an warga di Kepulauan TNS sudah menganut aliran Agama Protestan yang menjalankan banyak aktivitasnya dalam varian Melayu Ambon. Oleh karena koordinasi Gereja Protestan Maluku (GPM) berlangsung dari Kota Ambon, tidak mengherankan jika ketiga pulau kecil yang terletak jauh dan terpencil di daerah barat daya Laut Banda ini, penduduknya sudah lama terikat dalam jaringan sosial yang berpusat di Kota Ambon. Dengan sendirinya penggunaan BMA juga cukup intensif.

Beranjak dari konteks itu generasi penutur bahasa Yafila yang lahir dan dibesarkan di Pulau Seram tentu saja punya cerita yang berbeda dengan generasi yang lahir dan dibesarkan di Pulau Teon. Sekilas BYF masih terlihat lestari, tetapi kelestariannya cenderung teramati dalam komunikasi antargenerasi lanjut usia (> 50 tahun). Pada generasi transisi (26 - 50 tahun) tampaknya mulai berkurang, bahkan penurunan berlanjut pada generasi yang lebih muda (< 25 tahun). Namun, dalam keseharian kata-kata seperti inla 'tidur', imni 'minu', anti 'makan', roh 'mandi', krei 'gereja', iskola 'sekolah', woma 'rumah', porsa 'pintu', yanela 'jendela' masih sering digunakan. Begitu pula kalimat-kalimat pendek yang paling sering terdengar, antara lain $W a$ la war roh 'Saya mau pergi mandi', Um tikal lolu 'Dari mana kamu?', Um nle mai 'Mau ke mana kamu?', Wa la anti 'Saya mau makan'.

Untuk memperkirakan tingkat kekerapan penggunaan BYF, penelitian ini dilakukan pada ranah keluarga, pendidikan, dan ketetanggaan. Hal ini sejalan dengan pandangan Fishman (dalam Basuki Suhardi 2009: 21) bahwa penggunaan bahasa dalam suatu komunitas tutur (masyarakat bilingual) dapat diamati dan diteliti melalui berbagai ranah sebagai konteks tertentu atau tempat satu varian bahasa dianggap lebih tepat untuk digunakan daripada yang lain. Dalam hal ini ranah dipahami sebagai kumpulan aspek seperti lokasi, topik, dan peserta tutur. Seseorang dikatakan berada dalam ranah keluarga jika ia berbicara kepada anggota keluarganya, tentang topik sehari-hari seperti menu makanan, kunjungan keluarga, atau tugas setiap anggota keluarga.

Pada skala makro, konteks ranah yang digunakan tidak terlepas dari dinamika kehidupan manusia yang penuh dengan berbagai perubahan. Sztompka (dalam Pesurnay, 2010: 2) berpendapat bahwa dalam teori sistem, yang tergolong komponenkomponen utama perubahan adalah (i) perubahan komposisi, seperti migrasi dari suatu 
kelompok ke kelompok lain, pengurangan jumlah penduduk karena kelaparan, demobilisasi gerakan sosial, atau bubarnya suatu kelompok; (ii) perubahan lingkungan, seperti kerusakan ekologi, gempa bumi, munculnya wabah atau virus, atau lenyapnya sistem bipolar internasional.

Pandangan Sztompka ini berkaitan erat dengan migrasi suatu kelompok masyarakat untuk melangsungkan hidup di daerah lain yang lebih baik. Dikatakan lebih baik karena (i) migrasi pada dasarnya dipicu oleh masalah yang sangat besar terhadap daerah asal para migran. Misalnya, perang, kelaparan, serangan wabah atau virus tertentu ataupun, ancaman bencana alam; (ii) kelangsungan hidup di tempat yang baru merupakan permulaan dari hubungan-hubungan antarkelompok yang berbeda, tanpa jalur kekerabatan.

Keterkaitan antara konsep ranah dan konsep migrasi ini dijembatani dengan uraian Sumarsono (2002: 235) bahwa dalam penggunaan bahasa oleh seorang penutur atau sekelompok penutur sering terjadi pergeseran bahasa sebagai akibat dari perpindahan suatu masyarakat tutur ke masyarakat tutur lain. Artinya, kalau seseorang atau sekelompok orang penutur pindah ke tempat lain yang menggunakan bahasa lain dan bercampur dengan mereka, akan terjadi pergeseran. Bahkan Sumarsono menekankan bahwa pergeseran bahasa terjadi melalui alih generasi (intergenerasi) atau menyangkut lebih dari satu generasi. Jarang terjadi bahwa sejumlah besar individu dalam suatu masyarakat menanggalkan bahasa, dan mengganti dengan bahasa lain dalam kurun hidupnya.

Fishman dalam Grosjean (1982: 103-104) mengajukan skema bilingualitas yang memperlihatkan proses penggunaan bahasa para migran di Amerika, dan perkembangannya dalam pergantian antargenerasi.

Gambar (1a)

Skema Bilingualitas
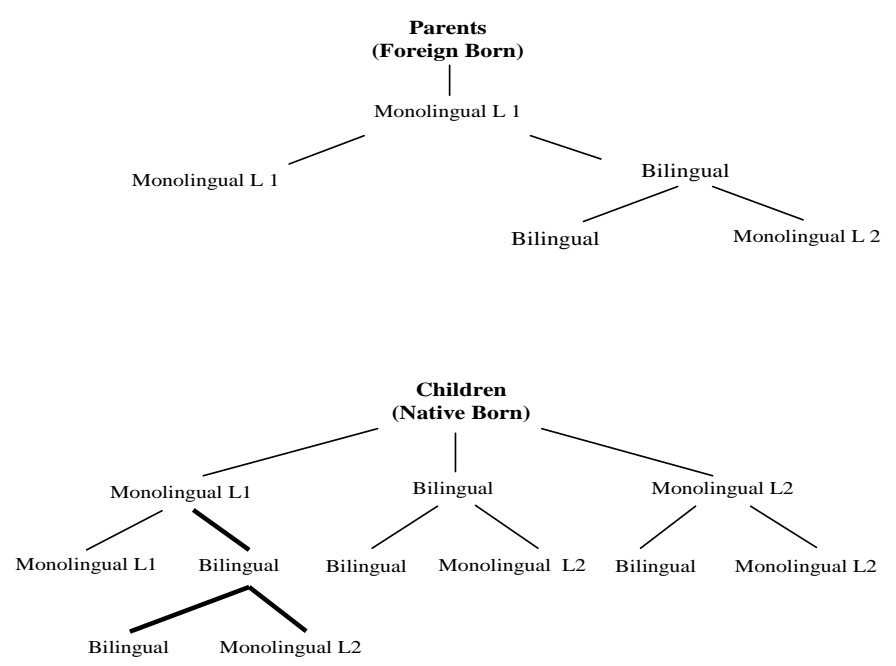

Skema tersebut dapat dijelaskan sebagai berikut. Para migran sebagai generasi pertama datang sebagai penutur yang monolingual. Sebagian generasi kedua masih monolingual, tetapi sebagian lagi sudah menjadi penutur yang bilingual, yang menggunakan bahasa lain di tempat yang baru atau lingua franca yang digunakan antara 
kelompok-kelompok yang tinggal di sekitar para migran. Oleh karena kekerapan penggunaan bahasa kedua pada akhirnya semakin tinggi, maka generasi ketiga dari para migran ini memperlihatkan pola yang lebih kompleks karena sebagian merupakan penutur yang bilingual antara bahasa dari generasi pertama dan bahasa kedua, sedangkan yang sebagian lagi sudah menjadi penutur bahasa kedua secara monolingual. Dengan perkataan lain, sebagian generasi ketiga sudah tidak lagi menggunakan bahasa generasi pertama, dan mungkin hanya mengetahuinya sebagai warisan budaya, tetapi tidak lagi mengenal bahasa tersebut sebagai alat komunikasi sehari-hari.

Oleh Chaer dan Leonie (2014: 144) skema Fishman ini lebih disederhanakan dengan hanya menyoroti pergeseran bahasa pada keturunan ketiga atau keempat para imigran itu sudah tidak mengenal lagi bahasa ibu (B-ib) orang tuanya, dan cenderung menjadi monolingual bahasa Inggris (B-in). Pergeseran bahasa para imigran itu dilukiskan dalam skema (1b) berikut.

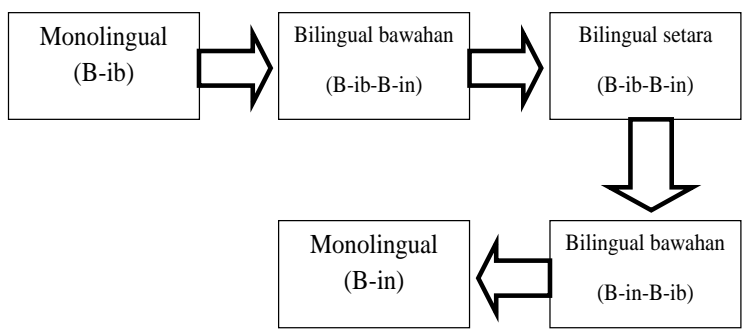

Pada kotak pertama, para imigran masih bermonolingual dengan bahasa ibu-nya (B-ib). Hal ini terjadi ketika mereka baru saja datang, dan beberapa tahun setelah itu. Setelah beberapa lama, sebagaimana yang digambarkan pada kotak kedua, mereka sudah menjadi bilingual bawahan (b-Ib \& b-In), tetapi bahasa ibu masih lebih dominan. Pada kurun waktu berikutnya, seperti yang tergambar pada kotak ketiga, bilingualism mereka sudah setara. Artinya, penguasaan bahasa Inggris sudah sama baiknya dengan bahasa ibu. Tampak kemudian, mereka menjadi bilingual bawahan kembali, tetapi dengan penguasaan bahasa yang berbeda: kini penguasaan terhadap bahasa Inggris jauh lebih baik daripada penguasaan terhadap bahasa ibu. Pada akhirnya, mereka menjadi monolingual bahasa Inggris; bahasa ibu atau bahasa leluhur sudah dilupakan.

Penggunaan bahasa oleh seorang penutur atau sekelompok penutur tidak jarang memperlihatkan fenomena pergeseran bahasa sebagai akibat perpindahan dari satu masyarakat tutur ke masyarakat tutur lain. Artinya, seorang penutur atau sekelompok penutur yang pindah ke suatu tempat yang menggunakan bahasa yang lain, lalu bercampur dengan mereka, akan mengakibatkan terjadinya pergeseran bahasa. Pendatang atau kelompok pendatang itu harus menyesuaikan diri dengan menanggalkan bahasanya sendiri, kemudian menggunakan bahasa setempat atau bahasa yang digunakan di tempat baru itu. Dalam kelompok asal, mereka memang dapat menggunakan bahasa pertama mereka. Namun, untuk berkomunikasi dengan orang lain (di luar kelompok) tentunya mereka tidak dapat bertahan untuk menggunakan bahasa sendiri. Sedikit demi sedikit mereka dapat belajar menggunakan bahasa penduduk setempat. 


\section{B. METODE}

Penelitian ini merupakan penelitian kualitatif yang memanfaatkan beberapa aspek yang lazim digunakan dalam penelitian kuantitatif, seperti penentuan variabel, penghitungan sampel dari populasi penutur yang ada, dan statistik deskriptif untuk membantu menjelaskan data berupa angka-angka (persentase).

Pengumpulan data dilakukan dengan menggunakan teknik observasi, angket atau kuesioner, wawancara, pencatatan, dan perekaman. Observasi yang dilakukan adalah observasi pasif, dan dilakukan sebelum angket atau kuesioner mulai dibagikan kepada para responden yang tergolong dalam ketentuan umur dan kuota pembagiannya masing-masing. Observasi dilakukan di dekat kios-kios samping sekolah yang menjual penganan kecil, dan biasanya dikunjungi oleh para siswa pada waktu istirahat; di dekat tempat anak-anak yang sedang bermain; di dekat tempat ibu-ibu atau bapak-bapak yang terlihat berkumpul; di lapangan pada saat orang-orang dewasa ataupun para remaja bermain bola; di ladang sambil menemani saudara lelaki atau paman yang mengolah ladangnya; di depan rumah pada saat para siswa pulang sekolah dan berjalan beramairamai sambil bercakap-cakap atau bercanda.

Melalui observasi peneliti berusaha mendekati masyarakat Desa Yafila untuk menjadi responden, dan bersedia mengisi kuesioner yang telah disediakan. Pengisian kuesioner tidak selalu dilakukan dalam situasi bersemuka (berhadapan langsung dengan responden), karena kadang-kadang responden meminta untuk mengisinya sendiri di rumah sesuai dengan penjelasan yang diberikan.

Kuesioner yang digunakan terdiri atas 25 pertanyaan pilihan ganda (multiple choice) yang meliputi ranah, yaitu ranah keluarga, pendidikan, pekerjaan, dan keakraban, dan ketetanggaan. Untuk setiap ranah terkandung lima pertanyaan. Pada ranah keluarga, pertanyaan penggunaan bahasa menyangkut komunikasi antara ayahibu, kakak-adik, kakek-nenek, paman-bibi, dan suami-istri. Pada ranah pendidikan, pertanyaan penggunaan bahasa menyangkut komunikasi antarguru, antarteman, antara siswa-guru, antara guru-siswa di luar kelas, dan antarpegawai. Pada ranah pekerjaan, pertanyaan penggunaan bahasa menyangkut komunikasi di ladang, di dalam perjalanan ke ladang, di kantor desa. Pada ranah keakraban, pertanyaan penggunaan bahasa menyangkut komunikasi dengan teman/sahabat yang ditemui di jalan, melalui telepon, dengan teman/sahabat yang dikunjungi dan mengunjungi, di tempat bermain, di dalam suatu perkumpulan. Pada ranah ketetanggaan, pertanyaan penggunaan bahasa menyangkut komunikasi antartetangga, dalam acara syukuran, acara pernikahan, dan keseharian di rumah tetangga. Setiap pertanyaan pada kuesioner memiliki tiga pilihan jawaban bahasa yang dominan digunakan responden, yaitu bahasa Yafila (BYF), bahasa Melayu Ambon (BMA), dan bahasa Indonesia (BI).

Jumlah responden yang akan mengisi kuesioner terlebih dahulu dihitung menurut jumlah penduduk setempat dan didasarkan pada umur minimal 12 tahun sampai dengan umur 60 tahun ke atas. Pertimbangan umur sebagai variabel didasarkan pada asumsi bahwa perkembangan dan pewarisan sebuah bahasa dapat diikuti melalui 
perjalanan dari satu generasi ke generasi berikutnya. Berbicara generasi tentu tidak terlepas dari pembicaraan menyangkut umur atau tingkatan umur.

Berdasarkan UU No. 52 Tahun 2009 tentang Perkembangan dan Pembangunan Keluarga yang dipadukan dengan pendapat Zakiah Daradjat (dalam www.suwarnatha.byethost) usia generasi dibatasi sampai seorang anak berumur 25 tahun. Jadi, generasi muda terdiri atas masa kanak-kanak ( 0 - 12 tahun), masa remaja (13 - 20 tahun), masa dewasa muda ( 21 - 25 tahun). Berarti, pembagian umur generasi itu mengikuti interval 25 tahun.

Oleh sebab itu, umur penutur BYF dibagi dalam 3 kelompok, yakni (i) kelompok umur 12-25 tahun; (ii) kelompok umur 26-50 tahun; (iii) kelompok umur $\geq$ 51 tahun. Kelompok yang pertama selanjutnya disebut kelompok generasi muda (GM), kemudian kelompok yang kedua diistilahkan sebagai kelompok generasi menengah atau generasi transisi (GT), dan kelompok yang ketiga dinamakan kelompok generasi lanjut usia (GL).

Bertolak dari rincian data penduduk Desa Yafila Tahun 2018 sebagaimana yang tampak dalam tabel di bawah ini.

Tabel (1)

Jumlah Penduduk Desa Yafila

Berdasarkan Kelompok Umur dan Jenis Kelamin

\begin{tabular}{|c|r|r|r|}
\hline $\begin{array}{c}\text { Kelompok } \\
\text { Umur } \\
\text { (tahun) }\end{array}$ & Laki-Laki & Perempuan & Jumlah \\
\hline $0-4$ & 40 & 27 & 67 \\
\hline $5--9$ & 42 & 50 & 92 \\
\hline $10--14$ & 55 & 41 & 96 \\
\hline $15-19$ & 50 & 45 & 95 \\
\hline $20-24$ & 29 & 39 & 68 \\
\hline $25-29$ & 28 & 25 & 53 \\
\hline $30-39$ & 72 & 67 & 139 \\
\hline $40-49$ & 45 & 45 & 90 \\
\hline $50-59$ & 29 & 23 & 52 \\
\hline$>60$ & 25 & 32 & 57 \\
\hline Jumlah & $\mathbf{4 1 5}$ & $\mathbf{3 9 4}$ & $\mathbf{8 0 9}$ \\
\hline
\end{tabular}

Sumber: Data Kantor Pemerintahan Desa Yafila Tahun 2018

Maka jumlah penutur yang akan diambil sebagai sampel penelitian diperoleh dari jumlah seluruh penduduk dikurangi dengan jumlah penduduk yang berumur di bawah 10 tahun, yang dalam perhitungannya adalah $(809-159=650)$. Dengan demikian, populasi penelitian ini adalah 650 penutur BYF. Sejalan dengan pembagian kelompok umur di atas, jumlah penutur yang berumur 12-25 tahun \pm 259 orang; penutur yang berumur 25-49 tahun \pm 282 orang; penutur yang berumur $\geq 50$ tahun \pm 109 orang.

Dengan rumus Slovin atau Taro Yamane (Riduwan \& Akdon, 2013: 249), yaitu

$$
\begin{aligned}
\mathrm{n}=\frac{N}{N \cdot a^{2}+1} & \\
\mathrm{n} & =\text { jumlah sampel } \\
\mathrm{N} & =\text { jumlah populasi } \\
\mathrm{d}^{2} & =\text { presisi (derajat kesalahan } 0,1)
\end{aligned}
$$


jumlah sampel penelitian ini dihitung sebagai berikut.

$$
\mathrm{n}=\frac{N}{N \cdot a^{2}+1}=\frac{650}{(650) \cdot 0,1^{2}+1}=\frac{650}{7,5}=86,67 \rightarrow 87 \text { orang }
$$

Artinya, jumlah sampel untuk penelitian ini adalah 87 orang penutur BYF di Desa Yafila. Berdasarkan jumlah tersebut, penghitungan sampel setiap kelompok umur atau generasi dilakukan dengan rumus $n i=\frac{N i}{N} \cdot n$ (Riduwan \& Akdon, 2013: 250).

$$
\begin{array}{lll}
\mathrm{ni} & = & \text { jumlah sampel menurut stratum } \\
\mathrm{n} & = & \text { jumlah sampel seluruhnya } \\
\mathrm{Ni} & = & \text { jumlah populasi menurut stratum } \\
\mathrm{N} & = & \text { jumlah populasi seluruhnya }
\end{array}
$$

Penghitungan dengan rumus tersebut dapat diuraikan sebagai berikut.

$$
\begin{aligned}
\mathrm{GM} & =259 / 650 \times 87=34,6 \rightarrow 35 \\
\mathrm{GT}=282 / 650 \times 87=37,7 & \rightarrow 38 \\
\mathrm{GL} & =109 / 650 \times 87=14,6 \rightarrow \frac{14}{87}
\end{aligned}
$$

Penghitungan tersebut mengartikan bahwa sampel kelompok GM (35 orang) diperoleh dari jumlah populasi GM (259 orang) yang dibagi dengan jumlah populasi penutur BYF (650 orang), kemudian dikalikan dengan jumlah seluruh sampel penelitian menurut umur atau generasi (87 orang). Berikutnya, sampel kelompok GT (38 orang) diperoleh dari jumlah populasi GT (282 orang) yang dibagi dengan jumlah populasi penutur BYF (650 orang), kemudian dikalikan dengan jumlah seluruh sampel penelitian menurut umur atau generasi (87 orang). Sampel kelompok GL (14 orang) diperoleh dari jumlah populasi GM, (259 orang) yang dibagi dengan jumlah populasi penutur BYF (650 orang), kemudian dikalikan dengan jumlah seluruh sampel penelitian menurut umur atau generasi (87 orang).

Dengan demikian, data penelitian ini adalah kekerapan penggunaan bahasa Yafila pada ranah keluarga, pendidikan, pekerjaan, dan keakraban, dan ketetanggaan. Istilah statistik untuk kekerapan adalah frekuensi. Oleh sebab itu, dalam penjelasan menyangkut metode distribusi tetap digunakan istilah frekuensi, sedangkan dalam pembahasan istilah yang digunakan adalah kekerapan.

Statistik adalah alat yang digunakan peneliti untuk memahami informasi. Dalam hal ini statistik yang digunakan adalah statistik deskriptif. Statistik ini digunakan untuk menjelaskan data kuantitatif sekaligus berfungsi mereduksi data agar lebih mudah diinterpretasikan. Dengan statistik deskriptif juga, data-data dapat dikelola dalam suatu cara yang bermakna dan peneliti dimungkinkan untuk mengumpulkan data secara random dan mengolahnya melalui beberapa aturan tertentu.

Metode statistik yang dimanfaatkan dalam penelitian ini adalah metode distribusi data. Penggunaan distribusi data didasarkan pada alasan bahwa data-data yang telah dikumpulkan membentuk berbagai pola distribusi yang tidak sama. Sebagai langkah awal data-data diatur dalam tabel distribusi frekuensi (Tabel 2), yaitu tabel nilai yang disusun berdasarkan derajat kepentingannya dan frekuensi kejadiannya. Tabel distribusi tersebut dibuat menurut interval kelompok umur sehingga responden dengan 
sendirinya telah kehilangan identitas individu dan melebur ke dalam identitas kelompok. Berikutnya, data yang di-input ke dalam kolom frekuensi penggunaan bahasa adalah jumlah penggunaan tiap bahasa dari 25 jawaban yang harus diberikan oleh responden sebagaimana yang tampak pada tabel di bawah ini.

Tabel (2)

\section{Distribusi Frekuensi Penggunaan Bahasa di Desa Yafila}

\begin{tabular}{|c|c|c|c|c|c|c|c|c|c|c|c|c|c|c|}
\hline \multirow{2}{*}{ 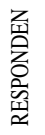 } & \multirow{2}{*}{ 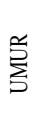 } & \multicolumn{3}{|c|}{$\begin{array}{l}\text { KEKERAPAN } \\
\text { PENGGUNAAN }\end{array}$} & \multirow{2}{*}{ 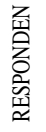 } & \multirow{2}{*}{$\sum_{S}^{\stackrel{S}{S}}$} & \multicolumn{3}{|c|}{$\begin{array}{l}\text { KEKERAPAN } \\
\text { PENGGUNAAN }\end{array}$} & \multirow{2}{*}{ 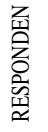 } & \multirow{2}{*}{$\stackrel{\text { 号 }}{\stackrel{s}{S}}$} & \multicolumn{3}{|c|}{$\begin{array}{l}\text { KEKERAPAN } \\
\text { PENGGUNAAN }\end{array}$} \\
\hline & & BYF & BMA & BI & & & BYF & BMA & BI & & & BYF & BMA & BI \\
\hline 1 & 12 & 13 & 11 & 1 & 36 & 26 & 15 & 8 & 2 & 74 & 51 & 15 & 10 & 0 \\
\hline 2 & 12 & 13 & 10 & 2 & 37 & 26 & 11 & 13 & 1 & 75 & 51 & 13 & 11 & 1 \\
\hline 3 & 12 & 9 & 15 & 1 & 38 & 27 & 14 & 10 & 1 & 76 & 52 & 15 & 10 & 0 \\
\hline 4 & 12 & 15 & 9 & 1 & 39 & 28 & 17 & 7 & 1 & 77 & 53 & 15 & 9 & 1 \\
\hline 5 & 12 & 10 & 13 & 2 & 40 & 29 & 14 & 10 & 1 & 78 & 54 & 14 & 10 & 1 \\
\hline 6 & 12 & 12 & 11 & 2 & 41 & 30 & 15 & 9 & 1 & 79 & 55 & 18 & 6 & 1 \\
\hline 7 & 12 & 12 & 12 & 1 & 42 & 30 & 12 & 12 & 1 & 80 & 56 & 9 & 14 & 2 \\
\hline 8 & 12 & 16 & 9 & 0 & 43 & 31 & 14 & 9 & 2 & 81 & 57 & 14 & 9 & 2 \\
\hline 9 & 13 & 11 & 13 & 1 & 44 & 32 & 13 & 11 & 1 & 82 & 58 & 13 & 10 & 2 \\
\hline 10 & 14 & 14 & 10 & 1 & 45 & 32 & 15 & 8 & 2 & 83 & 60 & 17 & 6 & 2 \\
\hline 11 & 14 & 9 & 15 & 1 & 46 & 33 & 15 & 9 & 1 & 84 & 61 & 15 & 8 & 2 \\
\hline 12 & 14 & 14 & 11 & 0 & 47 & 34 & 13 & 10 & 2 & 85 & 64 & 15 & 10 & 0 \\
\hline 13 & 14 & 14 & 9 & 2 & 48 & 35 & 12 & 11 & 2 & 86 & 70 & 16 & 8 & 1 \\
\hline 14 & 14 & 13 & 10 & 2 & 49 & 36 & 17 & 7 & 1 & 87 & 71 & 15 & 10 & 0 \\
\hline 15 & 15 & 12 & 11 & 2 & 50 & 37 & 12 & 12 & 1 & \multicolumn{2}{|c|}{ JUMLAH } & 204 & 131 & 15 \\
\hline 16 & 16 & 14 & 10 & 1 & 51 & 37 & 15 & 9 & 1 & & & & & \\
\hline 17 & 16 & 12 & 11 & 2 & 52 & 38 & 14 & 10 & 1 & & & & & \\
\hline 18 & 16 & 13 & 11 & 1 & 53 & 38 & 15 & 8 & 2 & & & & & \\
\hline 19 & 17 & 11 & 11 & 3 & 54 & 39 & 15 & 10 & 0 & & & & & \\
\hline 20 & 17 & 11 & 11 & 3 & 55 & 39 & 16 & 8 & 1 & & & & & \\
\hline 21 & 18 & 15 & 8 & 2 & 56 & 39 & 15 & 9 & 1 & & & & & \\
\hline 22 & 19 & 11 & 11 & 3 & 57 & 39 & 13 & 10 & 2 & & & & & \\
\hline 23 & 19 & 14 & 8 & 3 & 58 & 40 & 16 & 7 & 2 & & & & & \\
\hline 24 & 20 & 12 & 11 & 2 & 59 & 41 & 14 & 11 & 0 & & & & & \\
\hline 25 & 21 & 13 & 11 & 1 & 60 & 42 & 13 & 11 & 1 & & & & & \\
\hline 26 & 22 & 13 & 10 & 2 & 61 & 43 & 14 & 10 & 1 & & & & & \\
\hline 27 & 22 & 13 & 11 & 1 & 62 & 44 & 16 & 7 & 2 & & & & & \\
\hline 28 & 23 & 12 & 12 & 1 & 63 & 44 & 13 & 10 & 2 & & & & & \\
\hline 29 & 23 & 10 & 15 & 0 & 64 & 45 & 13 & 10 & 2 & & & & & \\
\hline 30 & 24 & 12 & 11 & 2 & 65 & 45 & 16 & 8 & 1 & & & & & \\
\hline 31 & 24 & 12 & 11 & 2 & 66 & 46 & 15 & 9 & 1 & & & & & \\
\hline 32 & 24 & 13 & 8 & 4 & 67 & 47 & 11 & 14 & 0 & & & & & \\
\hline 33 & 24 & 13 & 11 & 1 & 68 & 47 & 11 & 14 & 0 & & & & & \\
\hline 34 & 25 & 13 & 10 & 2 & 69 & 48 & 14 & 10 & 1 & & & & & \\
\hline 35 & 25 & 9 & 15 & 1 & 70 & 48 & 14 & 9 & 2 & & & & & \\
\hline \multicolumn{2}{|c|}{ JUMLAH } & 433 & 386 & 56 & 71 & 49 & 11 & 11 & 3 & & & & & \\
\hline & & & & & 72 & 49 & 13 & 12 & 0 & & & & & \\
\hline & & & & & 73 & 50 & 14 & 11 & 0 & & & & & \\
\hline & & & & & \multicolumn{2}{|c|}{ JUMLAH } & 530 & 374 & 46 & & & & & \\
\hline
\end{tabular}

Untuk pengecekan keabsahan data, digunakan teknik triangulasi metode dan sumber. Dalam hal ini data-data kekerapan penggunaan BYF yang diperoleh dari para responden yang mengisi kuesioner, kemudian dibandingkan dengan data-data hasil observasi, dan data-data hasil wawancara.

\section{PEMBAHASAN}

\section{Gambaran Umum Lokasi Penelitian}

Desa Yafila merupakan salah satu desa yang semula berada di Kepulauan Teon, Nila, dan Serua (TNS), tepatnya di Pulau Teon. Desa-desa lain yang juga terdapat di Pulau Teon adalah Desa Watludan, Desa Isu, Desa Mesa, dan Desa Layeni. Pada tahun 1978 masyarakat Kepulauan TNS dipindahkan ke Pulau Seram, akibat ancaman tiga 
gunung berapi aktif, yaitu G. Fausulu di Pulau Teon, G. Laworkarwa di Pulau Nila, dan G. Hutuloura di Pulau Serua (http://almascetie.wordpress.com)

Pada saat itu seluruh desa di Kepulauan TNS dipindahkan ke Pulau Seram, termasuk Desa Yafila. Semua masyarakat TNS dievakuasi ke Pulau Seram, tepatnya di Desa Makariki yang berjarak sekitar $20 \mathrm{~km}$ di sebelah utara Masohi sebagai Ibukota Kabupaten Maluku Tengah (Collins, 2018: 132). Selanjutnya, masyarakat ini dipindahkan lagi ke daerah Waipia di Seram tengah bagian selatan oleh pemerintah, yang kemudian dikenal sebagai Kecamatan TNS, dengan ibukotanya di Desa Layeni (Ayawaila, 2005: 18). Dalam proses perpindahan masyarakat TNS dari Desa Makariki ke Waipia, masyarakat Desa Yafila tidak ikut untuk berpindah karena masih berharap dapat kembali ke Pulau Teon.

Di Desa Makariki masyarakat Yafila tinggal selama 8 tahun yakni dari tahun, yakni dari tahun 1978-1986. Sesudah itu, masyarakat Yafila dipindahkan ke wilayah Kilometer 12 (yang lazim disingkat Kilo 12), dan berdiam di sana dari tahun 19872000. Perpindahan itu berlangsung sejalan dengan program transmigrasi lokal yang dilaksanakan oleh Bupati Maluku Tengah terhadap beberapa desa, yaitu Desa Banda Lama, Desa Sirisori, Desa Pelauw, Desa Kabauw, Desa Porto, Desa Nolot, dan Desa Yafila.

Oleh karena tata letak desa-desa tersebut relatif berjauhan, maka setiap desa menentukan jarak kilometer-nya masing-masing, dan disebut dengan istilah Kilo. Berdasarkan pengukuran jarak, Desa Yafila berada $12 \mathrm{~km}$ dari titik nol kilometer, di Makariki yang berada di tepi pantai, dan merupakan desa pertama sebelum adanya desadesa yang lain. Untuk itulah, dikatakan bahwa Desa Yafila berada di Kilo 12. Di situ masyarakat Desa Yafila bertetangga dengan masyarakat Desa Banda Lama, dan masyarakat Desa Sirisori. Masyarakat Desa Banda Lama merupakan masyarakat transmigran dari Pulau Banda, sedangkan masyarakat Desa Sirisori merupakan masyarakat transmigran dari Pulau Saparua.

Pada tahun 2001-2005 masyarakat Desa Yafila sempat berpindah ke Waipia karena imbas dari konflik sosial yang melanda Maluku. Setelah 4 tahun, masyarakat Yafila berpindah lagi ke negeri baru, yang termasuk dalam wilayah Kecamatan Amahai, Kabupaten Maluku Tengah, dan mereka menetap di sana sampai sekarang ini. Di tempat yang baru ini masyarakat Yafila bertetangga dengan masyarakat Bugis dari Kelurahan Hollo di sebelah Timur, dan di sebelah barat dengan Desa Jerili, Kecamatan Waipia (Monografi Desa Yafila, 2018).

Pada tahun 2006, pascakonflik sosial, sebenarnya masyarakat Yafila hendak kembali ke Kilo 12, tetapi ada beberapa alasan yang menyebabkan mereka akhirnya menempati bagian dari wilayah Kecamatan Amahai. Pertama, kepindahan masyarakat Desa Yafila tidak memperoleh izin dari Raja Negeri Sepa. Kedua, wilayah tersebut merupakan wilayah yang rawan banjir. Ketiga, lahannya tidak cocok sebagai lahan tanam.

Sumarsono (2002: 35) mengatakan bahwa pergeseran bahasa biasanya terjadi melalui alih generasi (intergenerasi) atau menyangkut lebih dari satu generasi. Jarang 
terjadi bahwa sejumlah besar individu dalam suatu masyarakat menanggalkan bahasa, dan mengganti dengan bahasa lain dalam kurun hidupnya. Oleh sebab itu, perkembangan dan pewarisan sebuah bahasa dapat diikuti melalui perjalanan dari satu generasi ke generasi berikutnya.

Berbicara generasi tentu tidak terlepas dari pembicaraan menyangkut umur atau tingkatan umur. Untuk itu, kekerapan penggunaan BYF akan dibahas berdasarkan kelompok umur atau generasi, dan dideskripsikan menurut ranah keluarga, ketetanggaan, dan pendidikan.

Seluruh data akan dianalisis dengan menggunakan angka persentase karena angka-angka absolut sukar dibaca, sedangkan angka persentase berfungsi untuk menekankan jumlah relatif tiap-tiap satuan, dan mengurangi pentingnya jumlah absolut (Tan, 1993: 314).

\section{Kekerapan Penggunaan BYF Berdasarkan Umur Penutur}

Tabel (3)

Kekerapan Penggunaan BYF Berdasarkan Umur Penutur

\begin{tabular}{|c|r|r|r|r|r|r|}
\hline \multirow{2}{*}{ BAHASA } & \multicolumn{5}{|c|}{ KEKERAPAN PENGGUNAAN } \\
\cline { 2 - 7 } & \multicolumn{2}{|c|}{ GM } & \multicolumn{1}{|c|}{ GT } & \multicolumn{2}{|c|}{ GL } \\
\cline { 2 - 7 } F & \multicolumn{1}{|c|}{ \% } & \multicolumn{1}{c|}{ F } & \multicolumn{1}{c|}{ F } & \multicolumn{1}{c|}{$\%$} \\
\hline BYF & 433 & $49 \%$ & 530 & $56 \%$ & 204 & $57 \%$ \\
\hline BMA & 386 & $44 \%$ & 374 & $39 \%$ & 131 & $39 \%$ \\
\hline BI & 56 & $7 \%$ & 46 & $5 \%$ & 15 & $4 \%$ \\
\hline JUMLAH & 875 & $100 \%$ & 950 & $100 \%$ & 350 & $100 \%$ \\
\hline
\end{tabular}

Persentase penggunaan bahasa berdasarkan umur penutur diperoleh dari jumlah penggunaan bahasa menurut setiap kelompok umur atau generasi. Pada kelompok umur 12-25 tahun atau generasi muda (GM), jumlah penggunaan BYF sebanyak 433; jumlah penggunaan BMA sebanyak 386; penggunaan BI sebanyak 56 yang dikalikan dengan 100, kemudian dibagi dengan jumlah seluruh penggunaan bahasa pada GM, yaitu 875 . Jadi, persentase penggunaan BYF pada GM sebesar 49\% diperoleh dari (433 x 100) / 875. Persentase penggunaan BMA sebesar 44\% diperoleh dari (386 x 100) / 875. Persentase penggunaan BI sebesar 7\% diperoleh dari (56 x 100) / 875.

Pada kelompok umur 26-50 tahun atau generasi transisi (GT) jumlah penggunaan BYF sebanyak 530; jumlah penggunaan BMA sebanyak 374; penggunaan BI sebanyak 46 yang dikalikan dengan 100, kemudian dibagi dengan jumlah seluruh penggunaan bahasa pada GT, yaitu 950. Jadi, persentase penggunaan BYF pada GT sebesar 56\% diperoleh dari $(530 \times 100) / 950$. Persentase penggunaan BMA sebesar $39 \%$ diperoleh dari (374 x 100) / 950. Persentase penggunaan BI sebesar 5\% diperoleh dari (46 x 100) / 950.

Pada kelompok umur $\geq 51$ tahun atau generasi lanjut usia (GL) jumlah penggunaan BYF sebanyak 204; jumlah penggunaan BMA sebanyak 131; penggunaan BI sebanyak 15 yang dikalikan dengan 100, kemudian dibagi dengan jumlah seluruh penggunaan bahasa pada GL, yaitu 335. Jadi, persentase penggunaan BYF pada GL 
sebesar 57\% diperoleh dari (204 x 100) / 335. Persentase penggunaan BMA sebesar $39 \%$ diperoleh dari (131 x 100) / 335. Persentase penggunaan BI sebesar 4\% diperoleh dari (15 x 100) / 335.

Terlihat bahwa BYF masih sering digunakan pada GM, tetapi nyaris berimbang dengan BMA. Salah satu penyebab bilingual setara adalah mobilisasi GM yang boleh dikatakan cukup tinggi ke Kota Ambon yang merupakan pusat pemerintahan Provinsi Maluku, yang masyarakatnya menuturkan BMA.

Pada GT kekerapan penggunaan BYF masih di atas 50\%. Namun, presentase tersebut tidak lagi menggembirakan. BYF cukup tersaingi oleh BMA, dan menjadi bilingual bawahan, tetapi dengan penguasaan bahasa yang berbeda: kini penguasaan terhadap bahasa Inggris jauh lebih baik daripada penguasaan terhadap bahasa ibu. Dari salah seorang responden merangkap informan, dikatakan BYF merupakan suatu peninggalan leluhur sehingga harus dilestarikan sebagaimana aspek budaya yang lain.

Selanjutnya, pada GL kekerapan penggunaan (BYF) adalah 57\%, (BMA) adalah $39 \%$, dan (BI) adalah 4\%. Sekalipun penggunaan BYF pada generasi ini cukup dominan, pergeserannya pun boleh dikatakan signifikan karena hanya $7 \%$ di atas skala menengah jika angka 50\% menjadi titik tengah.

\section{Kekerapan Penggunaan BYF pada Ranah Keluarga}

Untuk memperkirakan tingkat kekerapan penggunaan BYF, penelitian ini dilakukan pada ranah keluarga, pendidikan, dan ketetanggaan. Yang dimaksud dengan penggunaan bahasa pada ranah keluarga adalah penggunaan bahasa antara ayah/ibu, kakak/adik, kakek/nenek, paman/bibi, suami/istri, dan orang tua/anak-anak pada saat berkomunikasi sehari-hari. Sementara itu, ranah ketetanggaan adalah keterlibatan antara para penutur BYF dengan tetangga-tetangga di sekitar rumah. Selanjutnya, penggunaan bahasa pada ranah pendidikan adalah penggunaan bahasa di sekolah, antara guru/murid atau guru/pegawai di luar kelas atau di luar kegiatan belajar mengajar di kelas.

Tabel (4)

Kekerapan Penggunaan BYF pada Ranah Keluarga

\begin{tabular}{|c|r|r|r|r|r|r|}
\hline \multirow{2}{*}{ BAHASA } & \multicolumn{6}{|c|}{ KEKERAPAN PENGGUNAAN } \\
\cline { 2 - 7 } & \multicolumn{1}{|c|}{ F } & \multicolumn{1}{c|}{$\boldsymbol{\%}$} & \multicolumn{1}{c|}{ F } & \multicolumn{1}{c|}{$\boldsymbol{1}$} & \multicolumn{1}{c|}{ F } & \multicolumn{1}{c|}{$\%$} \\
\hline BYF & 83 & $47 \%$ & 108 & $56 \%$ & 51 & $72 \%$ \\
\hline BMA & 92 & $53 \%$ & 82 & $44 \%$ & 19 & $28 \%$ \\
\hline BI & 0 & $0 \%$ & 0 & $0 \%$ & 0 & $0 \%$ \\
\hline JUMLAH & 175 & $100 \%$ & 190 & $100 \%$ & 70 & $100 \%$ \\
\hline
\end{tabular}

Persentase penggunaan bahasa pada ranah keluarga diperoleh dari jumlah penggunaan bahasa menurut setiap kelompok umur atau generasi. Pada kelompok umur 12-25 tahun atau generasi muda (GM), jumlah penggunaan BYF sebanyak 83; jumlah penggunaan BMA sebanyak 92 yang dikalikan dengan 100, kemudian dibagi dengan jumlah seluruh penggunaan bahasa pada GM di ranah keluarga, yaitu 175. Jadi, persentase penggunaan BYF pada GM sebesar 47\% diperoleh dari (83 x 100) / 175. Persentase penggunaan BMA sebesar 53\% diperoleh dari $(92 \times 100) / 175$. 
Pada kelompok umur 26-50 tahun atau generasi transisi (GT) jumlah penggunaan BYF sebanyak 108; jumlah penggunaan BMA sebanyak 82 yang dikalikan dengan 100, kemudian dibagi dengan jumlah seluruh penggunaan bahasa pada GT di ranah keluarga, yaitu 190. Jadi, persentase penggunaan BYF pada GT sebesar 56\% diperoleh dari (108 x 100) / 190. Persentase penggunaan BMA sebesar 39\% diperoleh dari (82 x 100) / 190.

Pada kelompok umur $\geq 51$ tahun atau generasi lanjut usia (GL) jumlah penggunaan BYF sebanyak 51; jumlah penggunaan BMA sebanyak 19 yang dikalikan dengan 100, kemudian dibagi dengan jumlah seluruh penggunaan bahasa pada GL di ranah keluarga, yaitu 70. Jadi, persentase penggunaan BYF pada GT sebesar 72\% diperoleh dari (51 x 100) / 70. Persentase penggunaan BMA sebesar $28 \%$ diperoleh dari (19 x 100) / 70 .

Berdasarkan persentase pada tabel di atas dapat dikatakan bahwa BI tidak pernah digunakan ketika para penutur BYF berada di rumah. Baik GL maupun GT masih cenderung menggunakan BYF ketika berada di rumah, tetapi pewarisannya tidak berlangsung mulus terhadap GM. Hal ini tampak dari persentase penggunaan BMA yang lebih menonjol daripada BYF oleh GM ketika berada di rumah.

Dari hasil wawancara terhadap beberapa responden merangkap informan dari setiap generasi, ada dua alasan yang mirip antara satu dengan yang lain. Pertama, kebiasaan mereka yang sering berkunjung ke Kota Ambon, dan didatangi keluargakeluarga dari Ambon. Kedua, perkawinan antaretnis atau antarsuku yang membuat mereka harus menggunakan BMA karena bahasa daerah suami yang berbeda dengan bahasa daerah istri.

Collins (2018: 133) mencatat bahwa penduduk TNS sudah lama terikat dalam jaringan sosial yang berpusat di kota administratif provinsi, yaitu Kota Ambon. Contohnya, pada 6 Desember 1898 Gereja Protestan Maluku (GPM) sudah masuk di Pulau Serua; warga di ketiga pulau tersebut memang menganut aliran Agama Protestan yang menjalankan banyak aktivitasnya dalam varian Melayu Ambon. Bahkan kebaktian yang berlangsung di gereja menggunakan bahasa Indonesia. Tidak mengherankan walaupun ketiga pulau ini termasuk terpencil dari pusat pemerintahan Provinsi Maluku, mobilisasi penduduknya relatif tinggi.

\section{Kekerapan Penggunaan BYF pada Ranah Ketetanggaan}

Sama halnya dengan ranah keluarga, BI tidak digunakan sama sekali ketika penutur BYF berkomunikasi dengan orang-orang di sekitar rumah atau dengan para tetangga. Apabila disimak dengan saksama, tampak bahwa kekerapan penggunaan BYF pada ranah ini relatif tinggi. 
Tabel (5)

Kekerapan Penggunaan BYF pada Ranah Ketetanggaan

\begin{tabular}{|c|r|c|c|c|r|r|}
\hline \multirow{2}{*}{ BAHASA } & \multicolumn{6}{|c|}{ KEKERAPAN PENGGUNAAN } \\
\cline { 2 - 7 } & F & \% & F & \% & \multicolumn{1}{c|}{ F } & \% \\
\hline BYF & 127 & $73 \%$ & 146 & $77 \%$ & 53 & $76 \%$ \\
\hline BMA & 48 & $27 \%$ & 44 & $23 \%$ & 17 & $24 \%$ \\
\hline BI & 0 & $0 \%$ & 0 & $0 \%$ & 0 & $0 \%$ \\
\hline JUMLAH & 175 & $100 \%$ & 190 & $100 \%$ & 70 & $100 \%$ \\
\hline
\end{tabular}

Persentase penggunaan bahasa pada ranah ketetanggaan diperoleh dari jumlah penggunaan bahasa menurut setiap kelompok umur atau generasi. Pada kelompok umur 12-25 tahun atau generasi muda (GM), jumlah penggunaan BYF sebanyak 127; jumlah penggunaan BMA sebanyak 48 yang dikalikan dengan 100, kemudian dibagi dengan jumlah seluruh penggunaan bahasa pada GM di ranah ketetanggaan, yaitu 175. Jadi, persentase penggunaan BYF pada GM sebesar 73\% diperoleh dari (127 x 100) / 175. Persentase penggunaan BMA sebesar 27\% diperoleh dari (48 x 100) / 175.

Pada kelompok umur 26-50 tahun atau generasi transisi (GT) jumlah penggunaan BYF sebanyak 146; jumlah penggunaan BMA sebanyak 44 yang dikalikan dengan 100, kemudian dibagi dengan jumlah seluruh penggunaan bahasa pada GT di ranah ketetanggaan, yaitu 190. Jadi, persentase penggunaan BYF pada GT sebesar $77 \%$ diperoleh dari (146 x 100) / 190. Persentase penggunaan BMA sebesar 23\% diperoleh dari (44 x 100) / 190.

Pada kelompok umur $\geq 51$ tahun atau generasi lanjut usia (GL) jumlah penggunaan BYF sebanyak 53; jumlah penggunaan BMA sebanyak 17 yang dikalikan dengan 100, kemudian dibagi dengan jumlah seluruh penggunaan bahasa pada GL di ranah keluarga, yaitu 70. Jadi, persentase penggunaan BYF pada GT sebesar $76 \%$ diperoleh dari (53 x 100) / 70. Persentase penggunaan BMA sebesar 24\% diperoleh dari (17 x 100) / 70.

Menurut informasi yang diperoleh dari tokoh-tokoh masyarakat Desa Yafila, pola pemukiman mereka sengaja diatur menurut soa dan marga sehingga mereka dapat memelihara hubungan kekerabatan dan menjalankan kearifan setiap keluarga dan marga menurut tutur sejarahnya masing-masing. Pola pemukiman ini didasarkan pada aspek historis masyarakat adat di Kepulauan TNS yang dikategorikan atas (i) penduduk asli pertama; (ii) penduduk asli yang datang kemudian; (iii) penduduk pendatang yang datang setelah kesatuan adat terbentuk. Contohnya, di Pulau Teon selain penduduk asli setempat, ada juga penduduk yang datang dari Pulau Nila di sebelah utara, dari Pulau Luang, serta dari Pulau Wetan di Kepulauan Babar (Ayawaila, 2005: 23).

Bukan hal yang mengherankan bahwa ada penduduk Wetan yang pada akhirnya bermukim di Pulau Teon karena sebelumnya memang sudah ada hubungan sosial dan dagang yang terjalin antara penduduk di Pulau Teon dan penduduk di Pulau Wetan, Pulau Damar, dan Pulau Romang (Hasil wawancara dengan Bapak Nus Ukru pada tgl. 06 Januari 2019). Makanya, pada saat akan dievakuasi ke Pulau Seram, masyarakat 
TNS dikumpulkan di pos komando yang berada di Desa Wulur, Pulau Damar (Ayawaila, 2005: 17).

\section{Kekerapan Penggunaan BYF pada Ranah Pendidikan}

Menurut Thomason (dalam Basuki Suhardi 2001:39) kontak bahasa dapat terjadi melalui: (1) perpindahan sebuah kelompok ke tempat kelompok yang lain; (2) melalui hubungan budaya yang erat, (3) melalui pendidikan. Dalam hal ini, faktor pendidikan juga menyebabkan pergeseran bahasa seorang murid karena sekolah biasa mengajarkan bahasa nasional atau bahasa ragam resmi.

Jika dikaitkan dengan konteks ranah pendidikan yang berlokasi di luar kelas atau di luar kegiatan belajar mengajar di sekolah, ternyata BYF masih sering digunakan secara bergantian dan nyaris berimbang dengan BMA, terutama di tingkat SD. Para penutur BYF masih leluasa menggunakan BYF pada tingkat SD karena lokasinya yang berada di dalam Desa Yafila, dan ada guru yang dapat mengajarkan BYF dalam muatan lokal.

Pada tingkat SMP dan SMA, para siswa yang menuturkan BYF lebih banyak menggunakan BYF sebagai alat untuk menyampaikan hal-hal yang dianggap rahasia atau tidak perlu diketahui oleh teman-teman yang non-penutur. Selain itu, lokasi SMP dan SMA berada di luar desa atau di pusat kecamatan sehingga para siswa pada umumnya berasal dari berbagai desa di sekitar yang tidak berbahasa Yafila atau bahasa Teon. Jadi, mau tidak mau para siswa yang menuturkan BYF harus kerap menggunakan BMA dalam pergaulan mereka dengan para siswa dari desa lain yang tidak menuturkan BYF.

Tabel (6)

Kekerapan Penggunaan BYF pada Ranah Pendidikan

\begin{tabular}{|c|r|c|r|r|r|r|}
\hline \multirow{2}{*}{ BAHASA } & \multicolumn{6}{|c|}{ KEKERAPAN PENGGUNAAN } \\
\cline { 2 - 7 } & \multicolumn{1}{|c|}{ F } & \multicolumn{1}{c|}{$\%$} & \multicolumn{1}{c|}{ F } & \multicolumn{1}{c|}{$\%$} & \multicolumn{1}{c|}{ F } & \multicolumn{1}{c|}{$\%$} \\
\hline BYF & 73 & $42 \%$ & 73 & $38 \%$ & 32 & $45 \%$ \\
\hline BMA & 71 & $40 \%$ & 86 & $46 \%$ & 29 & $42 \%$ \\
\hline BI & 31 & $18 \%$ & 31 & $16 \%$ & 9 & $13 \%$ \\
\hline JUMLAH & 175 & $100 \%$ & 190 & $100 \%$ & 70 & $100 \%$ \\
\hline
\end{tabular}

Persentase penggunaan bahasa pada ranah pendidikan diperoleh dari jumlah penggunaan bahasa menurut setiap kelompok umur atau generasi. Pada kelompok umur 12-25 tahun atau generasi muda (GM), jumlah penggunaan BYF sebanyak 73; jumlah penggunaan BMA sebanyak 71; jumlah penggunaan BI sebanyak 31 yang dikalikan dengan 100, kemudian dibagi dengan jumlah seluruh penggunaan bahasa pada GM di ranah keluarga, yaitu 175. Jadi, persentase penggunaan BYF pada GM sebesar $42 \%$ diperoleh dari $(73 \times 100) / 175$. Persentase penggunaan BMA sebesar $40 \%$ diperoleh dari $(71 \mathrm{x} 100) / 175$. Persentase penggunaan BI sebesar $18 \%$ diperoleh dari $(31 \times 100)$ / 190.

Pada kelompok umur 26-50 tahun atau generasi transisi (GT) jumlah penggunaan BYF sebanyak 73; jumlah penggunaan BMA sebanyak 86; jumlah 
penggunaan BI sebanyak 31 yang dikalikan dengan 100, kemudian dibagi dengan jumlah seluruh penggunaan bahasa pada GT di ranah pendidikan, yaitu 190. Jadi, persentase penggunaan BYF pada GT sebesar 38\% diperoleh dari (73 x 100) / 190. Persentase penggunaan BMA sebesar 46\% diperoleh dari (86 x 100) / 190. Persentase penggunaan BI sebesar $16 \%$ diperoleh dari (31 x 100) / 190.

Pada kelompok umur $\geq 51$ tahun atau generasi lanjut usia (GL) jumlah penggunaan BYF sebanyak 32; jumlah penggunaan BMA sebanyak 29; jumlah penggunaan BI sebanyak 9 yang dikalikan dengan 100, kemudian dibagi dengan jumlah seluruh penggunaan bahasa pada GL di ranah pendidikan, yaitu 70. Jadi, persentase penggunaan BYF pada GT sebesar 45\% diperoleh dari (32 x 100) / 70. Persentase penggunaan BMA sebesar $42 \%$ diperoleh dari $(29 \times 100) / 70$. Persentase penggunaan BI sebesar $13 \%$ diperoleh dari $(9 \times 100) / 70$.

\section{Kekerapan Penggunaan BYF secara Umum}

Mengacu pada kekerapan penggunaan BYF menurut kelompok umur dan juga ditinjau dari beberapa ranah penggunaan, maka secara umum kekerapan penggunaan BYF dapat disimak pada tabel berikut ini.

Tabel (7)

Kekerapan Penggunaan BYF secara Umum

\begin{tabular}{|c|r|r|}
\hline \multirow{2}{*}{ BAHASA } & \multicolumn{2}{|c|}{ KEKERAPAN } \\
\cline { 2 - 3 } & \multicolumn{1}{|c|}{ F } & \multicolumn{1}{c|}{$\%$} \\
\hline BYF & 1,154 & $54 \%$ \\
\hline BMA & 880 & $41 \%$ \\
\hline BI & 116 & $5 \%$ \\
\hline JUMLAH & 2,150 & $100 \%$ \\
\hline
\end{tabular}

Persentase penggunaan bahasa secara umum diperoleh dari jumlah penggunaan setiap bahasa (lih. Tabel 2). Jumlah penggunaan BYF sebanyak 1.154; jumlah penggunaan BMA sebanyak 880; penggunaan BI sebanyak 116 yang dikalikan dengan 100, kemudian dibagi dengan jumlah seluruh penggunaan bahasa sesuai dengan respon penutur pada kuesioner, yaitu 2.150. Jadi, persentase penggunaan BYF sebesar 54\% diperoleh dari (1.154 x 100) / 2.150. Persentase penggunaan BMA sebesar $41 \%$ diperoleh dari $(880 \times 100) / 2.150$. Yang terakhir, persentase penggunaan BI sebesar 5\% diperoleh dari (116 x 100)/ 2.150 .

Jika persentase penggunaan BYF pada tabel di atas dihubungkan dengan pandangan bahwa seorang penutur atau sekelompok penutur yang pindah ke suatu tempat yang menggunakan bahasa yang lain biasanya menyesuaikan diri dengan menanggalkan bahasanya sendiri, kemudian menggunakan bahasa setempat atau bahasa yang digunakan di tempat baru itu, kasus di Desa Yafila berbeda.

Masyarakat migran ini tidak belajar menggunakan bahasa setempat karena daerah yang ditempati pada saat dievakuasi juga adalah daerah yang dikelilingi oleh masyarakat yang multietnis, seperti suku Jawa, Buton, Bugis, Makassar, Bali, juga keturunan bangsa lain seperti Cina dan Arab. Penutur BYF justru mengembangkan 
penggunaan BMA, yang sudah digunakan sewaktu masih di Pulau Teon, sebagai bahasa penghubung ketika berkomunikasi dengan para penutur yang berasal dari berbagai daerah di Maluku ataupun daerah-daerah di luar Maluku.

\section{KESIMPULAN}

Berdasarkan hasil analisis di atas dapat dikatakan bahwa kekerapan penggunaan BYF mulai bergerak ke skala yang relatif rendah tinggi karena secara umum hanya memperlihatkan persentase 54\%, di samping BMA yang sudah mencapai $41 \%$.

Menurunnya tingkat kekerapan penggunaan BYF oleh para penuturnya yang merupakan migran dari pulau kecil itu, tidak ditentukan oleh situasi geografis lokasi pemukiman sekarang dengan ekologi pulau besar. Penurunan atau pergeseran penggunaan BYF lebih disebabkan oleh faktor mobilitas penutur BYF ke Kota Ambon sebagai Ibukota Provinsi Maluku, keikutsertaan atau keterlibatan dalam dunia pendidikan, perkawinan antaretnis, pergaulan antaretnis.

\section{DAFTAR PUSTAKA}

Ayawaila, J.W., dkk. 2005. "Orang Teon Nila dan Serua di Maluku Tengah dan Perubahan Sosial". Laporan Penelitian Balai Kajian Sejarah dan Nilai Tradisional Ambon.

Chaer, Abdul dan Leonie Agustina. 2014. Sosiolinguistik: Perkenalan Awal. Jakarta: Rineka Cipta.

Collins, James T. 2018. Penelitian Bahasa di Maluku. Ambon: Kantor Bahasa Maluku,

Badan Pengembangan dan Pembinaan Bahasa, Kementerian Pendidikan dan Kebudayaan.

Grosjean, Francois. 1982. Life with Two Languages: An Introduction to Bilingualism. Harvard: Harvard University Press.

http://almascetie.wordpress.com. Diakses pada tanggal 01 Desember 2017, Pukul 14.00 http://regional.kompas.com. Diakses pada tanggal 26 November 2017, Pukul 18:53

Moelong, Lexi J. 2007. Metodologi Penelitian Kualitatif. Bandung: Remaja Rosdakarya

"Monografi Desa Yafila". 2018.

Morissan. 2012. Metode Penelitian Survei. Jakarta: Kencana.

Pesurnay, Charles Y. 2010. "Ekspansi dan Migrasi: Studi Kasus Negeri Besi Kapupaten Maluku Tengah Provinsi Maluku” dalam Jurnal Papua Vol.2 No. 2 November.

Riduwan dan Akdon. 2013. Rumus dan Data dalam Statistika. Bandung: Alfabeta.

Summer Institute of Linguistics (SIL) International Cabang Indonesia. 2006. BahasaBahasa di Indonesia. Jakarta.

Suhardi, Basuki. 2001. Pedoman Penelitian Sosiolinguistik. Jakarta: Pusat Bahasa. Sumarsono. 2002. Sosiolinguistik. Yogyakarta: Pustaka Pelajar.

Tan, Mely G. 1993. "Penggunaan Data Kuantitatif” dalam Koentjaraningrat (Ed.) Metode-Metode Penelitian Masyarakat (hlm. 251-268). Jakarta: Gramedia. www.suwarnatha.byethost. Diakses pada tanggal 25 Mei 2015, Pukul 22.23 WIT. 